\title{
Red herring unmasked: the trail leading to retinoblastoma
}

Variant Chee Nee Vern ${ }^{1}$, Chan Li Yen², Zayani Binti Zohari², Fazliana Binti Ismail ${ }^{1}$, Jamalia Binti Rahmat ${ }^{2}$

${ }^{1}$ Department of Ophthalmology, University of Malaya, Kuala Lumpur, Malaysia; ${ }^{2}$ Department of Ophthalmology, Hospital Kuala Lumpur, Ministry of Health, Kuala Lumpur, Malaysia

\section{Abstract}

This case series highlights the possibility of retinoblastoma in children with a history of trauma. Retinoblastoma commonly presents with leukocoria. In our series, the history of blunt trauma led to a misdiagnosis. The delay in correctly diagnosing retinoblastoma was made more difficult with hyphaema and vitreous haemorrhage obscuring the fundus view. Hyperdensities in imaging tests were mistaken for intraocular foreign bodies and post-trauma insult rather than calcification of an intraocular tumour. Both patients underwent anterior chamber washout. The patients were referred to our centre when their condition worsened. Retinoblastoma was highly suspected and confirmed from histopathological examination after enucleation. An accurate diagnosis can only be achieved by exercising a high index of suspicion. Misdiagnosis and mismanagement will lead to poor prognosis.

Keywords: hyphaema, retinoblastoma, trauma

Correspondence: Variant Chee Nee Vern, No 268, Reed, Jalan Tasik Damai, Taman Tasik Impian, Lake Fields, 57000 Sg Besi, Kuala Lumpur, Malaysia.

E-mail: variant.cnv@gmail.com 


\section{Abstrak}

Siri kes klinikal ini menunjukkan kemungkinan diagnosa retinoblastoma pada kanak-kanak yang mempunyai sejarah trauma. Retinoblastoma lazimnya menunjukkan simptom keputihan anak mata putih (leucokoria). Dalam kajian siri ini, adanya sejarah kecederaan tumpul telah menyimpang ketepatan diagnosa. Ini menjadi lebih sukar kerana pendarahan pada gelemair dan gelemaca menghalang pemeriksaan retina. Penemuan ujian pengimbasan imej disalah-tafsir sebagai benda asing intraokular dan komplikasi dari kecederaan, dan bukannya kalsifikasi tumor intraokular. Kedua-dua pesakit menjalani pembedahan pembuangan darah gelemair dan dirujuk ke pusat kami apabila keadaan mereka bertambah teruk. Retinoblastoma telah disyaki dan disahkan dengan histopatologi bola mata. Diagnosa yang tepat hanya dapat dicapai sekiranya mempunyai indeks kecurigaan yang tinggi. Kesalahan dalam diagnosa dan rawatan boleh menyebabkan prognosis yang buruk.

Kata kunci: pendarahan gelemair, retinoblastoma, trauma

\section{Introduction}

Retinoblastoma commonly presents as leukocoria (71.8\%). ${ }^{1}$ However, there have been a few reported cases which presented as hyphaema. ${ }^{2-3}$ We report two cases of retinoblastoma that were initially thought to be traumatic hyphaema but eventually led us to a more sinister diagnosis. We aim to remind the importance of being vigilant when treating young children.

\section{Case presentation}

\section{Case 1}

A 3-year-old girl presented with conjunctival redness for a month in her left eye. Her mother attributed it to frequent falls and therefore did not seek treatment. On examination, visual acuity in the left eye was light perception with grade 3 hyphaema, dense cataract, phacodonesis, and intraocular pressure (IOP) of 42 $\mathrm{mmHg}$. As there was no fundus view, B-scan ultrasonography (USG) was done and showed vitreous haemorrhage. The right eye was unremarkable. Anterior chamber washout was performed on the left eye. However, she developed eyelid swelling and worsening of conjunctival injection with fixed and dilated pupil 2 weeks later. Computed tomography (CT) of the orbit was ordered (to rule out orbital cellulitis), showing hyperdensity with calcification within the vitreous with peripheral enhancement of the left orbit and probable endophthalmitis (Fig. 1). She was referred to Hospital Kuala Lumpur. Retinoblastoma was suspected during 

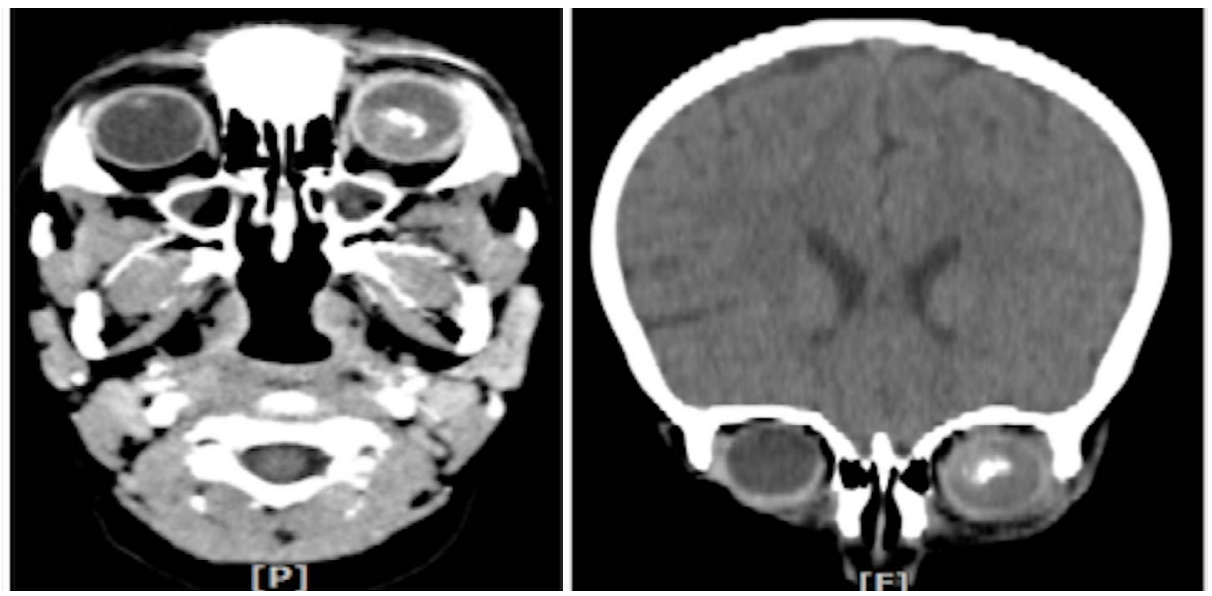

Fig. 1. Computed tomography of the orbit showing intraocular hyperdensities in the left eye.

examination under anaesthesia. B-scan USG showed vitreous opacity with calcification. The left eye was enucleated. The histopathological examination reported a solitary, endophytic tumour measuring $15 \mathrm{~mm}$ with intrascleral invasion, confirming the diagnosis of retinoblastoma.

\section{Case 2}

A 2-year-old boy presented with conjunctival redness in the right eye after being hit by an umbrella 1 day prior. Visual acuity of the right eye was light perception. On examination, there was an abrasion over the right lower lid, conjunctival injection, and total hyphaema with IOP of $31 \mathrm{mmHg}$. B-scan USG showed vitreous haemorrhage. Orbital CT reported irregular hyperdensity and probable intraorbital haemorrhage. However, a foreign body could not be excluded (Fig. 2). Anterior chamber washout was done in the right eye for non-resolving total hyphaema, but the eye remained injected and the vitreous haemorrhage persisted after the washout. Thus, he was referred to Hospital Kuala Lumpur. On examination, the right eye had exotropia, florid rubeosis iridis with shallow anterior chamber and dilated pupil. There was a retrolental mass with vessel engorgement underlying the vitreous haemorrhage. B-scan USG showed diffuse vitreous haemorrhage with central calcification. Retinoblastoma was highly suspected. RE enucleation was performed and HPE reported a single, $15 \mathrm{~mm}$ endophytic tumour not involving Bruch's membrane. 

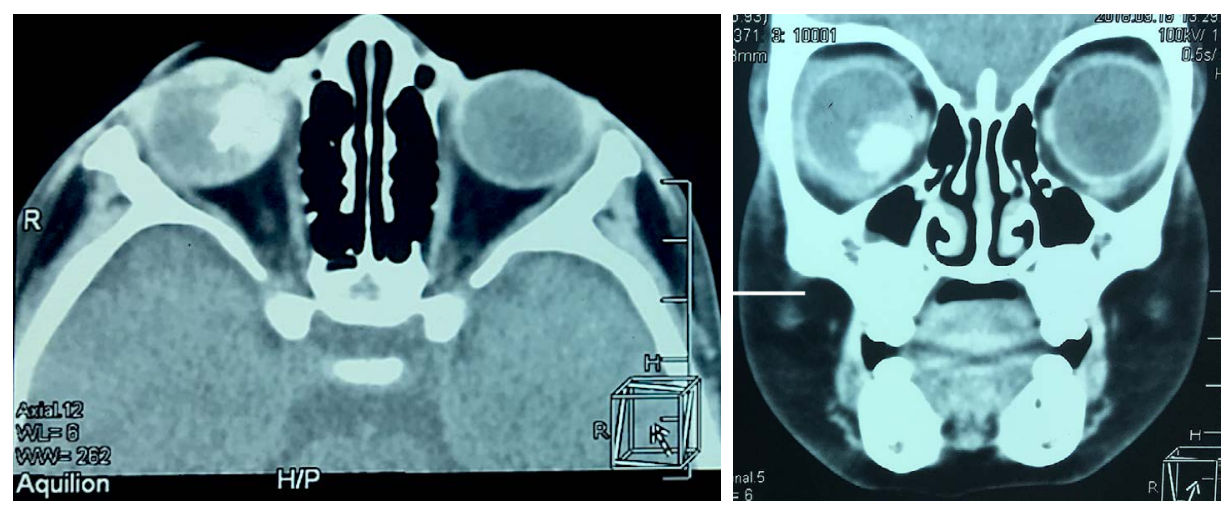

Fig. 2. Computed tomography of the orbit showing an irregular, hyperdense lesion in the vitreous of the right globe with surrounding periorbital fat streakiness.

\section{Discussion}

Hyphaema as the first presentation of retinoblastoma is rare. In a review by Balasubramanya, hyphaema was reported in only $0.25 \%$ of patients out of 392 retinoblastoma cases. ${ }^{2}$ In our local population of retinoblastoma, associated hyphaema is similarly uncommon (4.6\%). ${ }^{1}$

As children are prone to falls and injuries, it is common to attribute their eye pathology to trauma. Having a clear-cut history of trauma misled the treating ophthalmologists as seen in our reports. Misdiagnosis may lead to deadly consequences. Murthy et al. reported on a girl with total hyphaema following a trivial trauma in which the ultrasound finding was consistent with vitreous haemorrhage. She died from metastatic extraocular retinoblastoma despite intensive chemotherapy after hyphaema drainage. ${ }^{3}$ Kaliki et al. reported on 14 patients with retinoblastoma who were initially misdiagnosed and intraocular procedures were inadvertently performed. Treatment was initiated and, of the 14, eight had progressive disease and died before completion of treatment. ${ }^{4}$ In another study, ten patients presented with a history of trauma with three patients undergoing intraocular surgery before the diagnosis of retinoblastoma. Treatment was given and two patients died despite adjuvant therapy. ${ }^{5}$

Our cases posed a diagnostic dilemma, as there was no fundus view. Accurate diagnosis in such situations can only be made by means of a high index of suspicion of malignancy. Thus, we need to correlate the minimal findings found with the history given. In both cases the history was insufficient. When deemed suspicious, a thorough and detailed history taking is needed. For example, presence of other retinoblastoma features prior to trauma should be asked. If necessary, an examination under anaesthesia should be performed to ensure no crucial findings leading to diagnosis are missed, especially in uncooperative children. 
USG is safe, cost effective, non-invasive, and easy to use to look for hyperechoic tumours with calcifications. Precise interpretation, however, may be blinded by the history given. Although imaging can aid in the diagnosis of retinoblastoma, this case series shows that radiological interpretation is influenced by the clinical information available. In addition to retinoblastoma, there can be other causes of intraocular calcification, including intraorbital foreign body. The appearance of calcification and foreign body can be indistinguishable. Glass and silicone may have similar Hounsfield units to calcification. ${ }^{6}$ Clinicians also should be more meticulous in identifying imaging features that may indicate retinal tumours in children with history of trauma because of its similar characteristics to foreign bodies.

\section{Conclusion}

There needs to be a high index of suspicion of malignancy when dealing with cases of hyphaema following minor trauma in children. Retinoblastoma needs to be ruled out in young children with unexpected ocular findings, be it clinically or on imaging despite a history of trauma. Surgical intervention needs to be delayed, and prompt appropriate treatment is required in order to avoid a life-threatening outcome.

\section{Declarations}

\section{Ethics approval and consent to participate}

None.

\section{Consent for publication}

The authors certify that they have obtained all appropriate consent from the guardians. In the consent forms, the guardians have given their consent for the images and other clinical information to be reported in the journal.

\section{Competing interests}

None.

\section{Funding}

None.

\section{Acknowledgements}

The authors would like to thank the Director General of Health Malaysia for permission to publish this paper. 


\section{References}

1. Reddy SC, Anusya S. Clinical presentation of retinoblastoma in Malaysia: a review of 64 patients. Int J Ophthalmol. 2010;3(1):64-68.

2. Balasubramanya R, Pushker N, Bajaj MS, Ghose S, Kashyap S, Rani A. Atypical presentations of retinoblastoma. J Pediatr Ophthalmol Strabismus. 2004;41:18-24.

3. Murthy R, Honavar SG, Vemuganti GK, Naik MN, Reddy VP. Systemic metastasis following hyphema drainage in an unsuspected retinoblastoma. J Pediatr Ophthalmol Strabismus. 2007;44(2):120-123.

4. Kaliki S, Taneja S, Palkonda VAR. Inadvertent intraocular surgery in children with unsuspected retinoblastoma: a study of 14 cases. Retina. 2019;39(9):1794-1801.

5. Chen R, Ye H, Lin Y, et al. Head and Eye Trauma Before Retinoblastoma Diagnosis. Cancer Manag Res. 2019;11:10269-10274.

6. Gor DM, Kirsch CF, Leen J, Turbin R, Von Hagen S. Radiologic differentiation of intraocular glass: evaluation of imaging techniques, glass types, size, and effect of intraocular hemorrhage. AJR Am J Roentgenol. 2001;177:1199-1203. 